\title{
A Schematic Evaluation of the Impact of Heresies and Persecution in the Catholic Church: an Igbo Pragmatic Perspective
}

\author{
Maurice Izunwa \& Stanley Mgbemena*
}

\section{Abstract}

The history of Christianity and for that fact that of Catholic Church is long fraught with incidents of persecution and of emerging heretical doctrines. In many ways, the church has tried to contend with such afflictions to the security of life of her members and the integrity of her teaching authority and has found in each of them quite some rich resources for her continued existence and growth. While the blood of the martyrs is the seed of Christianity, the errors of heresy have at particular moments of the church's life, called the attention of the church to the need to much formally define her doctrines and often times elevating some of such doctrines to the status of irreformable dogmas presented to the faithful and requiring obedience of faith. After a brief comparative description of the nature and effects of persecutions and heresies, this work looks at the differential degrees of anxiety afforded to the Church by the dual events of persecution and heresy. It finds that heresies being invidious in outwork are dangerous to the faith of the Church which is its direct victim. It further finds that in a typical Igbo Christian community under the strong influence of a pragmatic worldview, heresies are a welcome experiment as they provide yet other pragmatic possibilities for resolving life's riddles and solving gnawing problems of human life through the religious pathway; persecution on the other hand, because it often visits with attack on life and physical integrity of Christians, is for the Igbo convert, detestable as it is ominous, life being the Igbo man's greatest good. This essay employs the method of phenomenology, analysis and hermeneutics in its investigation and recommends for a new 
era of evangelization of the Igbo Christians so as to align their spiritual sensibilities with the ancestry of Christian faith long demonstrated from the apostolic times till now in the lives of the martyrs.

http://dx.doi.org/10.4314/ujah.v13i2.6

\section{Introduction}

There is not and there never was on this earth, a work of 'human' policy, so well deserving of examination as the Catholic Church. The history of this Church joins together the two great ages of human civilization. No other institution is left standing which carries the mind back to the times when the smoke of sacrifice rose from the pantheon and when Camelopads were bounded in the flavian amphitheatre."

It is interesting to learn that no sooner had Christ instituted this mighty 'edifice' than the infant Church grew in influence and numbers. The religious freedom in the Roman Empire and the imperial association of Christianity with Judaism and thus 'religio licita' were partly responsible for such phenomenal expansion. The late discovery of the uniqueness of Christianity and its non-Judaic orientation plunged the Church into a threatening situation by the hostilities of the ruling powers of Rome. In fact, from the first century of its inception, the powers of the earth and hell arrayed themselves against Christ in the persons of his followers. It was Nero in 64AD who inaugurated this dismal culture of suppressions. Precisely in this, great numbers sealed their testimony with their blood. To be sure, Christ did forewarn the Church of this imminent distressing campaign saying "they will hand you over to be tortured" (cf. Mt. 24:9, 21,22; Jn. 15:26). 
It remains to be pointed out that with the edict of Milan in 313AD, Emperor Constantine in full solemnity, declared at the end of the decisive battle of the Melvian Bridge, "where the cross proved as effective a talisman against the armies of his rivals as against demons", that Christianity has become the religion of the Empire. Now that the Church had been spared of the persecutions and threats to the gospel from without, "Christians had the leisure to ponder over the truths of their religion." In this new-found speculative freedom, many fell headlong into theological errors or heresies. As it were, the battle line having been drawn from within the Church, she had to contend with doctrinal wrangling and discords within her ranks. Such doctrinal issues appertain to truths about the faith of the Christian religion. Suffice it to know that this latter threat became more drastically inimical to the life of the Church than the persecutions. In this, the biblical warning that "a kingdom divided against itself cannot stand" was proved as the heresies were close to shattering the fragile unity of the Christendom.

In this essay, after a brief analysis of concepts, an attempt will be made to discover the comparative differential impact of both persecution and heresy on the life of the catholic church in general and an Igbo Christian church in particular.

\section{Conceptual Framework}

The word Church is taken from the Greek kuriakos, "belonging to the Lord"; in the LXX GK, ekklesia, designates "a public assembly" or "synagogue," even "congregation." The Fathers of the Second Vatican Council define it as "the people of God." Generally, it designates the Christian Church, both local and universal." It is this sense of the word 'church' that is applicable to this essay.

Persecution means the effort by the civil authority to suppress or constrain the Church's liberty by physical or psychological means. It is about "the organised methods of the 
Roman emperors to extinguish, terminate, and marginalize Christianity which they saw as a threat to their empire." Persecution can be local or universal, direct or indirect. From Nero to Decius, all persecutions were local but when in 202AD Septimus Servus forbade all conversions to Christianity, persecution became universal. Persecution is direct when it has to do with exposure to imprisonment and death, and indirect with regard to "vulnerability before the law and public opinion and unfair administration of justice," etc.

Ordinarily heresy connotes "doctrinal deviation from the fundamental truths taught by Scripture and the Orthodox Christian Church and active propagation of the same." According to Canon 751, heresy is the wilful post-baptismal denial or doubt by a Catholic, of any truth which must be believed as a matter of Divine Revelation and taught by the Catholic Faith. In an ordinary sense of this work, heresy refers to false doctrine or the formal denial of doctrine defined as part of the catholic faith. Formal heresy involves "deliberate resistance to the authority of God, who communicates his Revelation ... to the Catholic Church. The punishment for it is automatic ex-communication" (cf. Can. 1364). Heresy is not a technical term in the modern canonico-theological sense. In Hellenism, heresy (heresies) 'to choose' meant "a teaching and a school". In Hellenic Rabbinic Judaism, it designates a religious party within Judaism. In this connection, the word has a neutral application and it is in this sense that St. Paul used it in Acts 26:5. But when St. Paul uses the term in a Christian context to mean 'Splinter groupings,' the meaning became pejorative. The Fathers of the Church emphasized the religio-moral side of heresy with its causes and consequences. They stressed also its co-operate divisive stance. In this period of the Fathers, it was shown that "not all errors are heresy" (St. Aug. Haer. Ph. 42:19). But then, a wilfully obdurate posture which turns its face against the whole Church and which swarms to form its own convectile is the mark of true heresy. 


\section{Persecution and its Impacts on the Church}

The Church was born in persecution starting with the death of Jesus Christ on the cross who said "if they have persecuted me, they will also persecute you". Hence to be a Christian means a summon to martyrdom. No surprise then that from the earliest times, "Christians have been objects of persecution in one form or another" (cf. Acts 5:1-3). Accordingly they have been persecuted by those who felt threatened by them; who sought to enforce religious conformity; who penalized dissent from accepted or established religious norm or belief and behaviour. The early persecutions in Rome came through the emperors, heralded by the draconic edict "Christiani non sunt". Principally, Christians were persecuted because of their refusal to sacrifice to the emperor and worship the Roman gods. They "risked their goods, freedom, and even their lives to confess the name of Christ." What is more, "laws were passed against the Christian faith and penalties imposed without mercy." According to John Bowle, the great persecutions "were carefully planned to destroy Christianity by confiscating its buildings and sacred literature, cutting off its endowments and separating the clergy from the laity."

It really did come to the point that, "St. Augustine was compelled to develop a Christian theory of coercion quite as cruel in its application as the persecution of Diocletian." To be sure, those persecutions did affect the Church very adversely. Perhaps a look at the Ten Great persecutions will reveal how enormous the hangovers were viz:

\section{Looking at the Great Persecutions}

\begin{tabular}{|l|l|l|}
\hline Emperors & Period & $\begin{array}{l}\text { Principal Impact } \\
\text { (Negative) }\end{array}$ \\
\hline
\end{tabular}




\begin{tabular}{|c|c|c|}
\hline Nero & 54-60 AD & $\begin{array}{l}\text { Burnt down Rome, } \\
\text { threw Christians to } \\
\text { the beasts and burnt } \\
\text { others, saw to the } \\
\text { death of Peter and } \\
\text { Paul. }\end{array}$ \\
\hline Domitan & 81-96 AD & $\begin{array}{l}\text { Wiped out the } \\
\text { cream Christian } \\
\text { membership i.e. the } \\
\text { Christian nobility. }\end{array}$ \\
\hline Trajan & 98-117 AD & $\begin{array}{l}\text { Attached a capital } \\
\text { punishment to the } \\
\text { profession of } \\
\text { Christianity and } \\
\text { forced Christians to } \\
\text { denounce their } \\
\text { faith or die. }\end{array}$ \\
\hline Marcus Aurelius & 161-180 AD & $\begin{array}{l}\text { Confiscated the } \\
\text { property of the } \\
\text { faithful and } \\
\text { tortured them. }\end{array}$ \\
\hline S. Severus & $193-211 \mathrm{AD}$ & $\begin{array}{lr}\text { Forbade } & \text { fresh } \\
\text { conversion } & \text { to } \\
\text { Christianity. } & \end{array}$ \\
\hline M. Thrax & $135-238 \mathrm{AD}$ & $\begin{array}{l}\text { Directed his } \\
\text { persecution to the } \\
\text { clergy and the } \\
\text { Religious. }\end{array}$ \\
\hline
\end{tabular}




\begin{tabular}{|l|l|l|}
\hline Decius & 249-251 AD & $\begin{array}{l}\text { Killed those who } \\
\text { refused to sacrifice } \\
\text { to the state gods. }\end{array}$ \\
\hline Valerian & $253-260$ AD & $\begin{array}{l}\text { He forbade all } \\
\text { Christian assembly } \\
\text { and concentrated } \\
\text { on wiping out the } \\
\text { clergy. }\end{array}$ \\
\hline Aurelian & $270-275$ AD & $\begin{array}{l}\text { Promoted anti- } \\
\text { Christian } \\
\text { legislation. }\end{array}$ \\
\hline Diocletian & $284-305$ AD & $\begin{array}{l}\text { Unleashed the } \\
\text { bloodiest of all } \\
\text { Roman } \\
\text { persecutions. }\end{array}$ \\
\hline
\end{tabular}

\section{The Positive Side of the Persecution}

Although the persecutions left behind, unexpected and enduring aftermath, it did help the Church as well because "the storms of oppositions made the flame of the gospel burn all the brighter." Finally, it is true that though "the persecutions the Church suffered in the empire during that time were extremely painful, they were extremely fruitful."

\section{An Appraisal of the Impacts of Heresy in the Catholic Church}

The medieval scholastics laid much emphasis on the moral aspect of heresy, that is, on the sin of heresy with its wilful, proud, isolation from the communion of the faithful, its contemptuous rejection of Church discipline and its tragic religious consequences for the life of the believer. 
Since the 17th and 18th century, heresy predominantly became "a doctrinal censure, designating objectively heterodox doctrines as that which contravenes a truth of divine and Catholic faith. In these contemporary times, the factor of personal guilt is being gradually reintegrated into the concept of heresy.

\section{Historical Importance and Development of Heresy in the Catholic Church}

Between the 4th and 5th centuries, the early Christian community was troubled by such heresies as: Arianism, Donatism, Nestorianism, Monophysitism, in the East, and in the West by Pelagianism. And by the 6th and 7th centuries, the Byzantine Empire was split over the question of monophytism as compounded by monothelitism. Earlier in the Middle Ages between $8^{\text {th }}-9^{\text {th }}$ centuries, "new study of the inherited theology of late antiquity resulted in the first truly medieval heresies: the filioque controversy, predestination, Eucharistic controversies as well as Adoptionism, Pantheism and Iconoclasm to be economical with enumeration. In the high Middle Ages between $11^{\text {th }}-12^{\text {th }}$ centuries, the following heresies flourished: Eucharistic heresies, Catharism and various sacramental and anti-sacerdotal heresies, Manichaeism and other heretical spiritualities. In the latter Middle Ages, the heretical high points were: the denial of transubstantiation by Wyclif and the denial of papal primacy by John Hus. At this period, the Church adopted inquisition as an anti-heretical tool.

\section{A Schematic Categorization of Heresies vis-à-vis Their Proponents and Errors}

The period that began with Constantine and lasted for more than one hundred years witnessed the unfolding of ten or more heresies, at least, with the most varied bearings on the points of dogma. Traditionally, these heresies have been placed under: 
(I) Trinitarian heresies: Arianism, Sabellianism, Adoptionism, et al.

(2) Christological heresies: Appoloniasm, Arianism, Nestroinaism, Diocetism, Monophysitism, et al.

(3) Sacramental heresies: Donatism, et al.

(4) Grace controversies: Pelagianism, et al.

At this point, a graphical portrait of few heresies, their proponents and teachings may serve a use.

\begin{tabular}{|c|c|c|c|}
\hline Heresies & Proponents & $\begin{array}{l}\text { Principal } \\
\text { Teachings }\end{array}$ & $\begin{array}{l}\text { Condeming } \\
\text { Council/Pope }\end{array}$ \\
\hline Arianism & Arius (311) & $\begin{array}{l}\text { Jesus Christ is } \\
\text { not God. He is } \\
\text { inferior to the } \\
\text { Father. }\end{array}$ & Nicea (325) \\
\hline Appolinarianim & Appolinarius & $\begin{array}{lr}\text { Denies } & \text { the } \\
\text { genuineness } & \text { of } \\
\text { Christ's } & \\
\text { humanity. } & \\
\end{array}$ & $\begin{array}{l}\text { Constantinople } \\
\text { (381) }\end{array}$ \\
\hline Nestorianism & $\begin{array}{l}\text { Nestorius } \\
(430)\end{array}$ & $\begin{array}{l}\text { Only one nature } \\
\text { in Christ. }\end{array}$ & Ephesus (431) \\
\hline Sabellianism & $\begin{array}{l}\text { Sabellius } \\
(200)\end{array}$ & $\begin{array}{l}\text { One God } \\
\text { revealed Himself } \\
\text { successively in } \\
\text { three modes. }\end{array}$ & $\begin{array}{l}\text { Pope } \\
\text { Callistus I }\end{array}$ \\
\hline Adoptionism & $\begin{array}{l}\text { Paul of } \\
\text { Samsota } \\
(260-272)\end{array}$ & $\begin{array}{l}\text { Christ is not } \\
\text { God. He was } \\
\text { adopted by the } \\
\text { Holy Spirit at } \\
\text { baptism. }\end{array}$ & $\begin{array}{lr}\text { Pope Adrian I } \\
(785) \text { and } & \text { Pope } \\
\text { Alexander } & \text { III } \\
(1177) & \end{array}$ \\
\hline
\end{tabular}




\begin{tabular}{|l|l|l|l|}
\hline Monophytism & $(448)$ & $\begin{array}{l}\text { One nature in } \\
\text { Christ. }\end{array}$ & Chalcedon (451) \\
\hline Donatism & Donatus & $\begin{array}{l}\text { Denial of Ex } \\
\text { Opera operato. }\end{array}$ & $\begin{array}{l}\text { Pope Miltiades } \\
(310-314) \text { and } \\
\text { council of Arles } \\
(314)\end{array}$ \\
\hline Pelagianism & $\begin{array}{l}\text { Pelagius } \\
\text { (400) etc. }\end{array}$ & $\begin{array}{l}\text { Denial of } \\
\text { original sin and } \\
\text { man's need of } \\
\text { grace. }\end{array}$ & $\begin{array}{l}\text { Carthage \& } \\
\text { Mileve (416) and } \\
\text { (417) Innocent I }\end{array}$ \\
\hline
\end{tabular}

\section{Negative Impacts of Heresies on the Catholic Church}

1. Heresies, precisely, as "heresies" meaning false doctrines which incite factions, shakes the foundation of the church. They break the unity which holds the people of God. The Alexandrian heresy for instance "split both bishops and the ordinary folk into camps which so fiercely attacked each other." In fact, the end result of every heresy is that the bond of charity that unites the hearts and minds of the community of believers is broken. Arianism, for example, left many bishops, monks, priests and faithful heretics, that is, breakouts from the orthodox faith.

2. The integrity of faith which is the life wire of the Church is always the victim of the heresies. Every heresy led to a particular form of faith crisis, because heretics command a stubborn faith attitude.

3. The more inimical aspect of any heresy is that it is an internal crisis - crisis launched from within the Church's ranks herself. Such a campaign is destined to be painful being perpetrated as it were by people who had shared the same faith. Thus "if this has been done by an enemy, but it is you my friend" (cf. Ps. 55:12). 
4. Another dangerous aspect of heretical doctrines is their resilience. For even after the councils have battled and subdued them "some of their ideas continued to reappear in later religious reformation of the 16th centuries." For instance, Primitivism, Quietism and Protestantism of the modern period are the many hangovers of formerly subdued heresies.

5. It is of the nature of heresies that they lead to the multiplication of the Churches. The great controversies of the early Church produced the separatist Churches of the Arians, Nestorians, Armenians, Copts and Jacobites. Same was the story of schism with Byzantium which resulted in the separation of the Greek and Latin Churches. It is for the same reason that "the Filioque of the Greek caused the rupture between Constantinople and Rome".

6. Precisely as internal crisis, heresies cannot be evaded by locomotion or flight. No, it can only be subdued at a great cost: prayer, counsel, councils and even much finance.

7. Ecclesial and imperial politics in addition to other problems provoked by heresies dragged theology into wrangling, rancour, vindictiveness and sometimes, led to persecution in the Church.

8. The emergence of heresies had always led the Church into multiplicity of rules in order to keep men in the path of true faith. A condition like this is not healthy for the freedom and spiritual growth of Christians.

9. Besides their faith implications, most heretical teachings led to social confusion and disaster. For instance, some people abandoned their jobs awaiting the Parousia at the teaching of Montanus.

10. Most heresies suffer from extremism and in this they caused a lot of religious and moral problem for the Church and State. Montanus taught, for example, that people should marry only once. When people's wives die, men supply with adultery what their faith denied them. As if not enough, Montanus preached that every Christian must have a 
recognizable spiritual gift. Now people go out hankering for gifts deceiving themselves and others especially in the Pentecostal Churches. What is more? Others sought for these gifts in the preternatural sources and the deep things of Satan in the abyss.

11. Just to arrest heretical teachings, the church was lured into unholy inquisitions in history. This has till date brought the Church bad tag and disrepute.

12. Some heresies made a mess of Christianity by denying the "incarnation". In this, they made Christianity more accessible to the pagans who were at loss to understand the idea of God made man.

13. In fact, every heresy has something defective to add to the progress of the Church and State.

\section{On Whether Heresies Have any Positive Impact on the Life of the Church}

Notwithstanding these devastating implications of heresies, they in some obvious ways do add value to the life of faith and the church in that:

1. Heresies woke the Church to active inquiry from speculative and systematic slumber, and helped Christians to fulfil the Petrine mandate: "always have your answers ready for people who ask you the reason for the hope you have".

2. In fact, had heretics not introduced the language of philosophy to define the content of their belief, the Church would not have employed the same language to define Catholic belief. Thus, in the Christological and Trinitarian controversies of the 4th and 5th centuries, the Church arrived at a fairly precise definition of nature, substance and person. This helped her to secure her Christological and Trinitarian dogmas.

3. When councils sit to address heresies, the acknowledgement and consolidation of disciplinary powers of the Church is made 
possible; some documents are also defined. For instance, the fight for Concilliarism led to the definition of the papacy and the relative authority of the councils, bishops and synods.

4. Heresies like Montanism pushed the Church to a more formidable control of prophecy and unusual spiritual powers and claims.

5. Almost all the councils came as a response-machine to a particular heresy. In this way heresies helped the Church to formulate and teach some articles of faith more impressively. For instance, Montanism helped the Church to study the relationship between God the creator and God the redeemer. In all, the council taught that God the creator and God the Redeemer are one and same God. However, it must be clearly observed that the devil of heresy is greater than its Angel.

\section{Heresy and Persecution: Which Is More Dangerous to the Pristine Faith of the Catholic Church?}

At the very threshold of the first Ecumenical Council in 325, Constantine declared: "I consider dissensions in the Church more dreadful and more painful than any other war". The above statement serves more than prove the case that heresy is more dangerous to the church than persecution. For one thing is clear, persecution is about external aggression but heresy comes from within the Church's rank to attack the church in the very core of her faith. Here, the axiom that "a kingdom divided against itself cannot stand" validly applies.

Heresy appears more inimical than persecution because it argues for unseriousness, lack of conviction and inconsistency in the Church's claims. And from this viewpoint, it confirms the claims of the persecutors, encourages them to the disfavour of the Church. Is it any surprise then to hear that heresies invite persecution and this is persecution in "excelsis"? When persecution was common place in the Church, Christians were united in an uncommon degree and thus the faith was phenomenally built up. Little wonder, 
Dennis Brutus wrote, "A common hate enriched our love and us". During the persecution, the believers with one faith, one God and one baptism, held each other in prayer, and thus became victorious. Hence, Tertullian wrote, "the blood of the martyrs is the seed of Christianity". But with the outbreak of heresies the Church knew division and when the centre could no longer hold together the edifice was threatened with a collapse.

The Church grew and spread in the conditions of the persecution. This is because while the Christians were evading their enemies they carried the gospel far and wide. Heresy breeds not just stagnation but goes further to make the faith less attractive and unacceptable, and thus spread becomes difficult. The resources available to the Church, are during outbreak of heresies, directed to rifts and defences than mission. During the persecutions as in all times of suffering, devotion and piety were encouraged, but heretical times favour rationalization to the detriment of Christian favour found in the religious experience of members and in devotion.

It can be argued that the persecutors helped to prove the divine origin of the Church. The peculiar way in which Christ and our fathers in faith like Stephen accepted suffering shows that they are witnessing to a divine milieu. Thus "father, forgive them for they do not know what they are doing". Heresies on the other hand do question the divine origin of the Church. This is because it is not very likely that a divine institution as that will be unsure of its claims giving rise therefore to discordant and rival doctrinal claims.

What is more, from the very words of the master, it is clear that persecution is even needed to confirm the faith of the elects; thus "whoever wants to be a follower of me, let him deny himself, take up his cross and follow me". But concerning heresy, He would say, "he who does not build with me scatters". Heresies in a very drastic way led the Church into the odious practice of inquisition. In this, the Church 
became a persecutor herself. This you can be sure, does not give a good picture of the Church with all its claims of a spiritual mission. In persecution, however, the Church suffered for the kingdom of heaven and in this way made her mission obvious. There is no gainsaying that while persecution can be evaded by flight, heresy cannot because its victim is the faith of the Church, and of its members. Also because heresy comes from among the members of the Church with the knowledge of the Church and her conditions, it cannot but be more disastrous.

Another dangerous truth is that while persecution comes and goes, heresies perdure in one or more configurations to harass the Church. In fact, "some of the heretical their ideas combine to reappear in later religious reformation especially of the 16th century". In all, it is no surprise that the Church had to suffer many persecutions in her earlier days because: "It is the customary fate of new truths to be persecuted only to emerge for final inauguration". The Christians always had a positive attitude to persecutions precisely because suffering has a salvific value in the Christian frame of reference. Little wonder Tertullian wrote of the Christian attitude to persecution saying, "afflict us, torment us, and crucify us - in proportion as we are mowed down, we increase, the blood of the Christians is a seed". A resort to the annals of Roman martyr ology and Church history had since proved this.

And so, irrespective of any importance which heresy could promise to the Church; for the fact that it is divisive, diminutive of piety and devotion, comprises the motherboard of schism and apostasy, and contradicts the prayer of Christ "ut unum sint", it is arguably more dangerous to the Church than persecution.

In this connection, Christians all over the world are encouraged to break off with internal strife among denominations to learn the more deeply, the saving doctrines 
of Christ, to emphasize more the things that unite them, to compose formidable frontiers of common network of evangelization, and above all to persevere in persecution whether from the government or persons or groups or other religions. Let courage rise with danger and strength to strength oppose. This day, the noise of battle, the next the victor's song.

\section{Paradigm Shift: The Pre-Eminence of Heresy Among the Igbo Converts to Catholicism}

The Igbo Catholic Christians are yet to completely extricate themselves from the ancestry of their traditional religions. As it were, the fact of their conversion is not total because their habit of faith interpretation is largely influenced by their traditional roots. It is for this reason that most of the Igbo converts to Catholicism are syncretic that is, attempting to produce a compromise between Christianity and pragmatism. In this equation, a strange category of understanding is observed, one in which heresy and not persecution is considered supremely advantageous to the faith community. This obviously contrasts with the pristine paradigm contemplated in the faith of the Apostolic Christians and that which the Church has taught through ages.

The Igbo sustain a very peculiar world-view, one in which life is of supreme value. Hence, it is no exaggeration to say that for the Igbo, the salvation of life in the body is the supreme law. There are more than sufficient evidence to demonstrate this penchant for life in the flesh, this nostalgia for material existence and all values incidental to it. Directly connected with the above temper to persist in existence is the fact that the Igbo abhors martyrdom and suffering, both of which are prejudicial to life on earth. These for him are evil and their cause must be found out so as to apply appropriate ritual remedy. Given this Igbo attachment to earthly life, death is an antithesis to an Igbo view of perfect life. Any pastor wanting to "seduce" the lgbo population at any Christian 
gathering needs only to advertise such biblical attractions as "you shall not die, you shall live" or "no weapon fashioned against you shall prosper" (Is 54:17). Without saying that the rest of humanity except the Igbo desire suffering and death, one would need to emphasize the fact that among the lgbo, all forms of sufferings except those arising from fruitful labour are punitive and valueless. Indeed, the idea of salvific capacity of "fruitless" sufferings is alien and unacceptable. Anything that imposes pain without an immediate reward in terms of improving life's condition is evil. Thinking on this idea J. Oguejiofor observed that:

... this world represents for the lgbo a certain summun bonum. An eternity where there is unbounded joy is not Igbo. The glory of good life is entrance into the company of the ancestors and reincarnation into the world in which one has formerly striven so hard to be morally and materially successfully. It is no wonder that the lgbo here on earth strive to make as much success as their power and intelligence permit. In their religious convictions, there is no reward hereafter for a life that is unsuccessful (both morally and materially) here below. Like the Jews of the Old Testament, they believe that material success is a supernatural blessing and that poverty is nothing but a curse.

Against this immediate backdrop, persecution is quintessentially a warrant of suffering, of death and of hideous physical and corporeal onslaughts against the believers. In persecutions, Christians are killed, some shot, some slain, others fed to wild beasts. What is more? Many are drowned, a lot more consumed in burning lakes of sulphur, a large number 
wasted by hunger or abandoned to crushing maladies, etc. No other explanation of these negations is available to the lgbo than the proposition that by abomination (nso ala), that is voluntary or involuntary breach of traditional norms, the gods are unleashing mystical sanctions not only on the individuals but on the society at large. The substance of the entire argument is that the Igbo who has the idea of this world as a closed system within which man oscillate to and fro, find it difficult to reconcile the kerygma of suffering in persecution with a theology of a future eschatology of bliss.

In the Igbo worldview, which is of very great influence on Igbo converts to Catholicism, whatever one gains here on earth is what he has and what he loses here on earth is what he has lost, there is no anticipated remedy or compensation promised to the righteous who have suffered here on earth. What this points to, is that, like all sufferings without immediate physical vital reward, persecution could not be associated with anything good or blessing for growth. Hence, the "lgbo Christian" in his unconverted cast will not likely find meaning in the celebrated slogan that "the blood of the martyrs is the seed of Christianity". Persecution becomes in this light a sign of ailing or failing faith. A Church under persecution becomes one under punishment by God for sins and offences unexpiated.

Next, the lgbo theory of action is quite a pragmatic one. Pragmatism is about the belief that the meaning of a doctrine is the same as the practical effects of adopting it. A belief is true if "it works satisfactory in the widest sense of the word". It insists on workability, demonstrability, cash value and satisfactory consequences. Neither do the Igbo contemplate insoluble problems nor do mysteries exist for them. In the Igbo world all things are possible and there is always a way to satisfy or fulfil each desire. Likewise, there is always a formula for getting round or circumventing an impasse. The formula is: predicting the effects by a diviner, determining the 
cause and applying prescribed remedies. In all these equations, survival is the principal pragmatic category; all other values are in service of that. As an ontological device to disabling impossibilities and so to take dominion over their world in the full sense of the word, the Igbo do neither conceive nor experience absolutes. There are no fixed points because reality as conceived by the Igbo has a distending elasticity with a plastic flexibility. In this way, permanent moral, social or metaphysical liabilities cannot be incurred. For instance, the Igbo will say and believe that the titled man (Nze na Ozo) must not tell lies (Nze anaghi asi asi). If he does, the consequence includes loosing communion with the ancestors. However, if a titled man who is a renowned liar dies, a ritual cleansing called "Isa ire' will be quickly applied to set-off and impeach the possible consequences of the lies he has told. Hence, there is no permanent moral liability and no constant in the lgbo world. Where gods fail in their duties and no longer live up to expectation, they are destroyed or carried away and other gods capable and ready to provide the desired effects are invoked and established. If an ancestor reincarnates to a family and it happens to be such an ancestor that one does not like, through requisite metaphysical manipulation called "Igbagha agu" the reincarnate ancestor will be exchanged for another who is desired. All abominations have grave consequences on persons and society but these consequences can be shortchanged, manipulated and/or redirected or even annulled by the designs of an expert medicine man or priest. There is a remedy for an ogbanje child and disturbing dead persons can be chained. Business failures can be put to an end by appeal to some ancient calculus without improving on the stock-in-trade and business capital, monitoring the incidents of demand and supply or working out routine income and expenditure account. What is more? The seasons are neither under any immunity nor are they invariable and this is because, the course of nature, seasons and times can be changed at the 
instance of any contingency. Rains can be made to fall midway the dry season and so even the bifurcation of the seasons provides no absolute. In fact, any device that can bring desired results is a welcome instrument for existential construction.

Heresies, you can be sure, come to compromise doctrines in order to justify certain preferred convenient practices and challenge other hard teachings. They appear to present an escape from the hostilities of the world and provide other options for salvation to humanity. As a matter of fact, heresies occasion some form of flight from life's intensities and attempts to use religion to undergird and insulate further, the heretic's personal options. Notice that people are susceptible to heretical teachings because:

... in one form or another, they nurture and reflect the way we would have it be rather than the way God has provided, which is infinitely better for us. As they lead us into the blind alleys of self indulgences and escape from life, heresies pander to the most unworthy tendencies of the human heart.

In this way, heresies assume the nature of some selfish device for subjective satisfaction. It tallies with what Fulton Sheen said to the effect that "Minds no longer object to the Church, because of the way they think, but because of the way they live, they no longer have difficulty with the creed, but with her commandments; they remain outside her saving waters not because they cannot accept the doctrine of Three Persons in One God, but because they cannot accept the moral of two persons in one faith; not because infallibility is too complex but because the veto on Birth control is too hard; not because the Eucharist is too sublime, but because Penance is too exacting. Briefly, the heresy of our day is not the heresy of thought; it is the heresy of action". 
Given the pragmatism of the Igbo race and their plural cultural synthesis demanding differential standards of satisfaction, each on its own right and merit, the Igbo man does not appear to see rival doctrinal positions - heresy, as a threat to religion but as a rich matrix for survival. It is about diversity in unity. If anything what is heretical for the Igbo is any doctrinal claim to absolutism, by implication all conservative doctrines are heretical. The orthodox is the multiple, the workable, the contingent and the consequential. Religion as religion should be able to ease off people's lives and bail their burden and not otherwise. It is there to generate variable devices sufficient enough to make men soar to their unfettered aspirations. When doctrines restrain, the Igbo is likely to see that as mere technicalities organized to persecute. Against this background, heresies which come to propound "false" doctrines of conveniences become salvific instruments. What matters is not the consistency but the workability. The question is, does it work? If yes, it is doctrinally salvific and orthodox. For instance, in the emerging lgbo Christianity today, we find in the Churches a wide range of superstitions and so heretical teachings about ancestors, life-after death, healing, poverty, fertility and infertility of men and women, etc. The Pentecostal Churches are at the vanguard of such heretical crusades. In the Catholic Church, the Charismatics, Precious Blood groups and some Marian movements are in the lead of these weird teachings. Unfortunately, some few priests in search of relevance have been drafted into the campaign. A whole range of these teachings come by way of nipping the "inconvenient" official doctrines in the bud and thus to supervene some convenient doctrinal shorthand for personal and group designs. In all, for a typical Igbo convert to Christianity, persecutions are evil, because they destroy life while heresies are blessings because they try out other options for salvation in the bodily realm. 
Worse still, we find among the Igbo, inertia to change from this fluid vision of reality. The Church must therefore intensify catechesis so as to encounter a whole race and engross them into the spirit of the Book and the vision of the new religion of Christianity.

\section{Conclusion}

The Church does not pray for persecutions nor heresies to breakout. But were any or both to come, the Church of the New Testament is always sufficiently armed to incorporate either or both of them to her best advantages. Suffering and so persecutions cannot be swept off the arrays of human life and nature. For "even in the centuries that enjoy high levels of advancement, suffering still exists in different forms. Generally speaking, although a lot of progress has been recorded in various fields of human endeavour, yet experiences of suffering remain". What is more? Notwithstanding the divisive character of heresies, and how much the Church fights to prevent them, whenever they indicate, the Church while condemning them as to impeach their sundering effects and consequent moral dangers, at once deploys them to advance the economy of the Church's growth.

In the Igboland, the Church has an uphill task, which is urgent and which consists in strong evangelization of the native peoples. While selecting for enculturation the elements of the Igbo worldview that can serve faith, the rest must never be compromised. With peculiar Christian theodicy the Igbo understanding of suffering for instance must be catechised and at the same time, true faith must be sufficiently advanced to address the excesses of pragmatism accompanying the Igbo worldview. The true and the pragmatic are not the same. While the true belongs to the order of saving grace, the workable belongs to the order of self-indulgence and utility calculus. Thus, generally, heresies are much more dangerous to the experience of the Church than persecutions. But among the 
typical Igbo converts to Christianity the experience is otherwise, that is, persecutions are more dangerous.

\section{Recommendations}

If the Church in the modern world, especially in the IgboAfrican sub-region will draw still more from the rich resources of the two enemies of the Christian faith -persecution and heresy, it is hereby recommended as follows:

1. That the Church should prepare modern Christians for the eventuality of persecution by strongly contradicting the Pentecostal and African religious teachings that all suffering is evil. This should be done through the pulpits, books and tele-evangelisation, where men should be taught that Christ having sanctified suffering, nothing good comes easy, and eternal life being the highest good, is highest in the scale of preference of a Christian man.

2. That the Church should launch a new era of evangelisation in the Igboland, so as to re-direct the traditional religious hangovers of the Christian beliefs of the new converts.

3. That once more, among the Igbo and the west, where a culture of materialism is fast emasculating the faith vision of the people, the nobility and sanctity of martyrdom should be taught and praised through all evangelical means, so as to gradually raise convinced Christians who will be ready to defend their faith, and fight heresy with the sacrifice of their life and blood.

4. That doctrinal instructions relating to all faith convictions of the Church should be enhanced, so as to instil in the members the sense of iniquity of heresy and to further prepare them, to recognise and confront same wherever and in whichever form it surges forth. 
5. That the Church will not always wait until a particular doctrinal or moral error has gained prominence and/or ascendency before it is condemned officially; but that the Church should now and again scout for dissenting doctrinal position in their gestation stages and condemn them with the strongest insistence on the faith of the Church.

*Maurice O. Izunwa PhD \& Stanley C. Mgbemena are lecturers of law and religion respectively in the Nnamdi Azikiwe University, Awka, Anambra State, Nigeria.

\section{References}


Allison, F. C. The Cruelty of Heresy An Affirmation of Christian Orthodoxy, (London, SPCK, 1994) P.17.

Blackburn, S. Oxford Dictionary of Philosophy, (New York, Oxford University Press, 1996) P. 297.

Baus K. et al, The Imperial Church from Constantine to the Early Middle Ages, (London, Burns and Oats, 1980) p. 16.

Boer, H. R. A Short History of the Early Church, (Ibadan, Daystar, 1976) p.44.

Bowle J. ed. The Concise Encyclopedia of World History, (London, Hutchinson pub. 1958) p. 116.

Demarest, B. "Heresy" in S. B. Ferguson and D. F. Wright (eds.), New Dictionary of Theology, (Leicester, InterVarsity Press, 1988) p.291-292.

De Koster, L. "Church" in Walter Elwell ed. The Concise Evangelical Dictionary of Theology, (London, Marshal Pickering, 1993) p. 98.

Ekarika, J. P. History And Doctrines of the Christian Church, (Venice, Christian pub., 1986) p.5.

Flanneery A. (ed), Documents of the second Vatican Council vol.1, Lumen Gentium, par. 9-17.

Furioli A., In God's Name: the Mystery of Human Suffering and the Anointing of the Sick, (Italy, Gaba publication, AMECEA., Eldoret, 1987), p. 1-5.

Hardon, J.A. Modern Catholic Dictionary, (London, Robert Hale, 1980) pp 417.

Henry, Thomas in A. Smith and B. Jacobson (edds.)The Nations Health, (London, Kings Fund, 1988) p.151.

La Monte, J. L. The World of the Middle Ages, (New York, Appleton, 1949) p. 411. 
Matthew 7:1ff; Mark 3:24

Macaulay B. in Edinburgh Review, 72(1840) pp. 227-228, quoted by Jaki in And on this Rock, (Virginia, Trinity Comm. 1987) p. 53-54.

Nwagbala E. A., Early Christian Reconciliation And Igbo Tradition, (Aachen, Shaker Verlag, 2002), P.319.

Oguejiofor, J. O. The Influence of Igbo Traditional Religion on the Socio-Political Character of the Igbo, (Nsukka, Fulladu Publishing Company, 1996) P.82

Raginald F. and A. Walter., Prime of Church History, (Dublin, M.H. Gill, 1959) p.5.

Rops, H. D. The Church of Apostles and Martyrs, (New York, J.M. Dene and Sons Ltd. 1960) p. 454.

Sheen, F. J. Communism and the Conscience of the West, (New York, Bobbs - Merril, 1948) PP. 142 - 143. 